\title{
Fenomena Penggantian Fonem pada Kata Celaan di Kalangan Remaja
}

\author{
Fajar Kurniadi \\ Fakultas Ilmu Pendidikan dan Pengatahuan Sosial, Universitas Indraprasta PGRI Jakarta \\ fajar.kurniadi@unindra.ac.id
}

\begin{abstract}
Abstrak
Perkembangan bahasa mengikuti perkembangan manusia dan interaksinya. Berbanding lurus antara semakin beragam dan banyaknya interaksi manusia. Terutama di kalangan remaja, di mana interaksi dan pergaulan adalah hal yang harus dilakukan demi mengembangkan potensi di berbagai bidang. Tidak ayal lagi, pemerolehan dan penggunaan bahasa remaja pun beragam. Keberagaman ini merupakan warnawarni dalam pergaulan, di antaranya sapaan akrab, tempat berkumpul, media sosial, dan berbagai topik pembicaaan kekinian termasuk kata celaan. Sebenarnya kata celaan ini digunakan sebagai candaan semata, tetapi tidak jarang juga mengundang emosi. Oleh karena itu, terdapat fenomena baru dalam dunia kebahasaan remaja dengan mengganti beberapa fonem atau susunan fonem pada kata celaan agar lebih terdengar halus dan tidak menyinggung. Adapun tujuan penelitian yang dilakukan selama tiga bulan ini adalah menangkap perilaku bahasa remaja dalam penggunaan kata celaan. Metode yang digunakan adalah observasi dan wawancara (tidak terstruktur) pada lebih dari 300 responden. Hasilnya pun mengejutkan, fenomena menggunakan kata celaan sudah dianggap lumrah dan menjadi bumbu dalam pergaulan. Beberapa kata celaan seperti (maaf) "Anjing” mengalami pengubahan menjadi “Anjay”, atau "Anjrit”, atau "Njiir". Demikian hal nya pada kata (maaf) "Kampret" mengalami pengubahan menjadi "Kamvret" dan beberapa kata lain yang mengalami pengubahan fonem.
\end{abstract}

Kata Kunci: Fonem, Celaan, Remaja

\section{PENDAHULUAN}

Bahasa mengikuti perkembangan manusianya, karena bahasa lahir, berkembang, dan akan mati di tengah interaksi manusia. Lahir dari keterampilan paling dasar manusia yakni menyimak. Dari hasil menyimak, seorang bayi mengenal dunianya dan menangkap serta beradaptasi dengan sekalilingnya. Dari hasil menyimak, bayi pun mengenali aroma, wajah, termasuk bahasa yang diarahkan kepadanya. Bahasa pertama yang diterima seorang bayi adalah saat inisiasi dini, di mana sang bayi merasakan hangatnya tubuh sang ibu dan menyusu untuk pertama kalinya. Lewat kegiatan ini, bayi berhasil mendapatkan ikatan bahasa dengan ibunya dengan aroma, suara, degupan jantung, dan kasih sayang. Selanjutnya, giliran sang ayah yang memberikan bahasa dengan mengumandangkan adzan atau ayat suci al-Quran sebagai pengenalan kepada Tuhan dan agama kepada bayi.

Beranjak menuju pematangan alat indera, bayi pun mulai dapat mengucapkan apa yang ditangkapnya melalui proses menyimak. Semakin banyak yang ia simak, semakin baik proses bicaranya. Begitu pula dengan lingkungan, semakin beragam ia berinteraksi dengan berbagai lingkungan, pola berbicara dan bahasanya pun akan semakin kompleks.

Masalah terjadi jika seorang anak mendapatkan bahasa dari berbagai lingkungan kehidupan. Anak yang belum mengetahui benar-salah atau baik-buruk tidak mempunyai penyaring yang ia ucapkan. Apa yang ia ucap adalah dari apa yang didengarnya. Jika hal ini terus terjadi, maka akan menjadi kebiasaan di masa depan.

Berbeda dengan pola bahasa anak, pola bahasa remaja jauh lebih kompleks. Meskipun mereka sudah mengetahui benar-salah atau baik-buruk suatu ucapan, mereka kadang terperangkap pada situasi sulit di tengah pergaulan. Kesulitan itu terjadi kala mereka berhadapan 
dengan bahasa yang mungkin dianggap tabu untuk dikatakan namun menjadi sebuah hal yang lumrah dalam pergaulan. Mengucapkan kata-kata tersebut adalah sebuah kesalahan, sedangkan jika tidak berarti dianggap tidak gaul. Pada akhirnya, mereka akan mendapatkan pengasingan atau dikucilkan dari pergaulan.

Salah satu fenomena yang sedang marak terjadi adalah pelumrahan kata celaan dengan mengganti beberapa fonem sehingga terdengar lebih "halus" dibandingkan kata asalnya. Selain dinilai lebih "halus", fenomena ini pun dianggap dapat meminimalisasi kesalahpahaman sehingga tidak ada yang tersinggung, baik yang sudah memahami atau yang tidak memahaminya.

Berdasarkan fenomena ini, peneliti berusaha menangkap kata celaan tersebut dan kecenderungan penggunaannya pada bahasa keseharian remaja dalam bergaul.

\section{LANDASAN TEORI}

\section{Remaja}

Berdasar usia, remaja adalah manusia yang mulai beranjak dewasa baik secara fisik dan psikologis. Tidak ada batasan usia yang jelas antara anak, remaja, dan dewasa. Tertulis dalam UndangUndang Perlindungan Anak pasal 1 ayat 1 bahwa "Anak adalah seseorang yang belum berusia 18 (delapan belas) tahun, termasuk anak yang masih dalam kandungan.“

Berdasarkan penjabaran tersebut, penelitian ini berfokus pada manusia berusia 17-25 tahun. Selain dilihat dari usia, remaja pun terikat dengan status sosial dan akademik. Remaja ditandai dengan manusia yang sudah seusia anak sekolah pada jenjang SMA hingga perguruan tinggi.

\section{Bahasa Celaan}

Celaan merupakan hasil dari mencela berupa kecaman atau kritikan. Kata celaan digunakan saat seseorang tidak suka atau sependapat dengan ucapan, pandangan, tindakan dari lawan bicaranya. Namun, terjadi kecenderungan bahwa kata celaan ini telah bergeser dari maknanya. Kata celaan dianggap sebagai kata pemantas dalam pergaulan. Akibatnya, tidak hanya dalam kondisi mengecam atau mengkritik, kata celaan tidak asing dan akrab dalam keseharian para remaja.

Kata celaan berbeda dengan kata makian, makian bermakna penggunaan kata yang keji berlandaskan rasa marah. Makian punya kadar emosi yang lebih tinggi dibanding celaan. Tanpa bermaksud membenarkan penggunaan kata celaan, tentunya.

\section{METODE PENELITIAN}

Penelitian ini menggunakan metode observasi dan wawancara. Peneliti melakukan observasi langsung kepada lebih dari 302 remaja usia 17-25 tahun. Penelitian ini berlangsung selama tiga bulan dengan responden acak secara jenis kelamin, yakni 123 laki-laki dan 179 perempuan. Cakupan wilayah yang diteliti adalah daerah Jakarta Timur khususnya pada mahasiswa Universitas Indraprasta PGRI yang ditemui secara acak sesuai tuturannya. Peneliti melakukan komunikasi intensif dan berusaha membaur dengan responden pada situasi santai.

\section{TEMUAN}

Beberapa temuan yang peneliti dapatkan selama tiga bulan adalah sebagai berikut berdasarkan jumlah penutur terbanyak: 


\section{Kata "Anjing"}

Anjing merupakan hewan berkaki empat yang tidak asing lagi dalam kehidupan manusia. Entah bagaimana, hewan ini selalu menjadi "primadona" saat seseorang merasakan kekesalan dan kemarahan yang tak tertahan kepada sesamanya atau benda di sekitarnya. Padahal, tidak ada kaitan antara kemarahan dengan hewan yang memiliki indera pencuiman dan pendengaran yang luar biasa ini. Bahkan, (Bahasa, 2008) bahwa "Anjing adalah binatang menyusui yang biasa dipelihara untuk menjaga rumah, berburu, dan sebagainya.” Melihat pada teori ini, anjing digolongkan pada hewan yang punya banyak manfaat bagi manusia.

Baiklah, kita kesampingkan masalah apa dan bagaiman kata "Anjing” dianggap sebagai kata populer saat meluapkan emosi. Faktanya, kata ini memang paling sering didengar dalam bahasa remaja untuk meluapkan emosi atau candaan. Namun, beberapa orang kadang merasa tersinggung dan tidak nyaman mendengarkan. Oleh karenanya kata ini mengalami pengubahan fonem menjadi "Anjay", “Anjrit”, "Njiir”, dan "Anjas".

Kata-kata ini pun menjadi "bumbu" dalam pergaulan remaja. Bukan hanya untuk menghaluskan celaan, saat mereka merasa ada sesuatu yang mengejutkan (entah baik atau tidak), mereka pun akan spontan mengucapakannya. Kata-kata ini dianggap lumrah dan menjadi kewajaran, seseorang akan dianggap tidak gaul jika tidak mengucapkannya.

Tidak hanya dalam pengucapan, di berbagai lini masa yang mereka miliki pun, bahasa ini banyak digunakan. Melihat fenomena ini, muncul kekhawatiran tentang kelanjutan kesantunan berbahasa pada remaja di lini masa atau media sosial.

\section{Kata "Bego"}

Bego merupakan kata yang bermakna sangat bodoh. Kata ini merupakan kata yang juga menjadi favorit saat mencela. Untuk menghindarkan kesalahpahaman, kata ini banyak diubah menjadi "Hego" atau mengubah fonem "B" menjadi "H". Selain itu, kata bego pun diubah menjadi bege. Mengubah fonem $\mathrm{O}$ menjadi fonem E dan diucapkan dengan ekspresi tertentu.

\section{Kata "Tolol"}

Bak serupa namun tak sama, kata Tolol merupakan celaan yang umum didengar dari tuturan remaja. Kata ini diubah menjadi Tulul sehingga justru dianggap lucu oleh para remaja.

\section{Kata "Kampret"}

Serupa dengan kata Anjing, kampret pun sebenarnya merupakan nama binatang yang biasanya disebut kelelawar kecil pemakan serangga atau buah-buahan. Kampret merupakan hewan yang aktif di malam hari. Hingga artikel ini ditulis, peneliti pun masih tidak mengetahui asal-muasal mengapa kampret biasa didengar dari para remaja saat mencela atau dalam pergaulan. Kata ini biasanya diganti menjadi Kamvret. Tidak hanya dalam lisan, beberapa lini masa remaja pun menggunakan bahasa ini sebagai bahan candaan dan mengekspresikan diri.

\section{Kata "Buset"}

Rasanya, kata ini sudah sangat lumrah didengar dari para remaja sebagai ekspresi keterkejutan, keheranan, dan kekagetan. Tidak jelas pula sumber dari kata ini. Kata ini biasanya diubah menjadi ucet, atau sheh. 


\section{KESIMPULAN}

Berdasarkan penelitian ini, peneliti dapat menarik beberapa simpulan diantaranya,

1. Terjadi pergeseran norma pada penggunaan bahasa di kalangan remaja.

2. Terjadi ketidaknyaman para remaja dalam pergaulan sehingga menggunakan kata celaan bahkan saat mereka tidak ingin mencela.

3. Terjadi pemodifikasian kode bahasa tertentu di kalangan remaja untuk menghaluskan kata celaan agar nyaman didengar.

\section{DAFTAR PUSTAKA}

Bahasa, P. (2008). Kamus Besar Bahasa Indonesia. Jakarta: PT Gramedia Pustaka Utama.

Undang-Undang Republik Indonesia Nomor 23 tahun 2002 Tentang Perlindungan Anak. 